\title{
An Assessment of Public Health Economy in Katsina State
}

\section{Abubakar $\mathrm{UL}^{1}$ and Abdurrahman $\mathrm{A}^{2}$}

${ }^{1}$ Federal Polytechnic Kaura Namoda, Zamfara State, Nigeria

${ }^{2}$ Al-Qalam University Katsina, Katsina State, Nigeria

\begin{abstract}
Health is generally an intrinsic human right as well as a central input to poverty reduction and socio-economic development. Better health is central to human happiness and well-being. It also make an important contribution to economic progress as healthy population live longer, are more productive, and more prone to saving more. This paper critically assessed the public health economy with a particular reference to accessibility, manpower distribution and major health problems in Katsina state. The paper used primary and secondary data based on the research objectives and important health indicators respectively. Descriptive statistical techniques were used in the presentation, analysis and discussions of data. Findings of the paper show that, doctor to population ratio stood at 1:67,415; ratio of nurses to population stood at 1:16,086; ratio of midwives to female population was put at 1:13,423. High blood pressure, diabetes and infectious diseases were found to have great impact on overall community health. Likewise, drug abuse, dropping out of school, and being overweight are the three (3) important risky behaviors that may generate or trigger health tension in the area. However, healthy behavior and life styles, access to health care services and clean environment are the factors which could improve the quality of life in the area. It was also found that, drugs for major health problems are free in the study area, there is awareness as regards to free health care services delivery in the area triggered by NGOs' intervention. Conversely, it was found based on the average mean scores that, there is no availability of health manpower in the state, no sufficient beds, wheel-chairs, ambulances and other health infrastructure in the state. There is no sound interconnection and feedback between primary health care units, secondary health care unit and tertiary health care unit. It is in the wake of these findings the paper calls on government, concerned agencies and community stakeholders to institute the spirit of volunteerism, philanthropism and humanitarianism to ensure adequate supply of health manpower, health infrastructure, public health awareness, accessibility to health services and more often than not establish a friendly and healthy environment that will pave ways for new economic, social and political dawn in the realm.
\end{abstract}

Keywords: Health; Infrastructure; Manpower; Economy

\section{Introduction}

The history of mankind is in many respects the history of its diseases. Infectious disease has been a more deadly enemy to man than war, hence the ghastliness of the modern concept of bacteriological war fare. When one studies the constant epidemics of the past and its deficiency diseases it is amazing that mankind has survived at all. Armies and empires have been brought low by disease. Malaria decimated the hosts of Sennacherib before Jerusalem and helped to complete the down fall of the Roman Empire. Of some 300,000 crusaders who left Western Europe in 1096 on the first crusade only 20,000 finally reached the Holy city. Bubonic plague destroyed a third of the people of medieval Europe, creating economic and social chaos. Small pox played a large part in the conquest of the New World by Spanish conquistadores and English puritans. Typhus killed 300,000 French soldiers in the peninsular war and completed the ruin of Bonaparte's Moscow campaign [1].

Studies on the nexus between health and economy have well documented in the literature (e.g. Arrow [2]; Bhutta [3], Garanne \& Gakusi [4], WHO [5,6], World Bank [6] and Lucas [7] etc.).

Public health care is an important aspect of the tradition of progress, prosperity, and development. It is in view of this, that federal, state and local governments in Nigeria have continue to devote resources and supply adequate means of addressing the ailing health dilemmas in every nook and cranny of the country at large. Public health economy aims at achieving the highest level of physical, mental, social, moral, and spiritual health for all citizens on a public basis. It seeks to do this by first, identifying the root causes of all prevalent diseases and health problems, and then dealing with them through a judicious utilization of governmental public resources.
Consequently, due to the weak and inefficient management of public health for all the citizens, Katsina state government in collaboration with the local governments decide to revitalize the health sector management owing to its advantage, importance, and implications socially, economically, politically, and otherwise. Despite the fact that, health care service delivery is gaining increasing attention from government, community and NGOs alike, yet, it is not uncommon for people in Katsina state to fall sick and die of diseases that can easily be cured and or prevented. The most remarkable challenge facing those areas was the issue of maternal and infant mortality. The people of the area especially those that reside in the extreme part of the state are suffering from malaria, cholera, measles, ulcer, small pox, diarrhoea, and typhoid to mentioned but a few. Presently, poverty is the most dramatic quandary threatening the public health status in Katsina state. Katsina state Ministry of Health lamented that, if no urgent action is taken by the authorities in charge, a greater untimely death will of course be inevitable $[8,9]$.

Nonetheless, this paper seeks to specifically provide answer to the

*Corresponding author: Abdullahi Abdurrahman, Al-Qalam University Katsina, Katsina State, Nigeria, E-mail: abdulabdul04@yahoo.com

Received December 11, 2018; Accepted December 26, 2018; Published December 31, 2018

Citation: Abubakar UL, Abdurrahman A (2019) An Assessment of Public Health Economy in Katsina State. Health Econ Outcome Res Open Access 4: 160. doi: $10.4172 / 2471-268 x / 1000160$

Copyright: ( 2018 Abubakar UL, et al. This is an open-access article distributed under the terms of the Creative Commons Attribution License, which permits unrestricted use, distribution, and reproduction in any medium, provided the original author and source are credited. 
most pressing question of whether equity and equality in the provision of health care services as enshrined in the constitutional frame work of the country is really considered and taken with dignity and hospitality or not? Equally vital was the need to critically examine the efficacy of health care service delivery, in which case, priority will be vested on comparative assessment across the state and country at large. Consequently, this study examines the daunting problems facing the Nigeria's health economy, and that of Katsina state [10].

In addition, lack of available beds, inadequate health facilities, drugs, and more importantly scarcity of manpower are serious menace to the health sector in Katsina state. Yet, government has come up with new system of health care that involve health education frequent sanitation of the environment, supplying drugs freely to certain diseases, etc. all in the name of achieving efficiency in the level of per capita health services in the society as a whole [10].

It is in the wake of the above background that this paper seeks to uncover the public health economy with reference to accessibility, manpower distribution and health infrastructure and major health problems in Katsina state.

\section{An Overview of Katsina State Health Economy}

Katsina state was created on September $23^{\text {rd }}$, 1987. It has an area of 23,938 square kilometers and a population of 5.97 million people based on 2003 population census figures at $3.0 \%$ constant annual growth rate) in 2007, this indicates a population density of about 249 persons per square kilometer [10].

There are approximately 1,312,598 Women of child Bearing Age (WCBA 15-49 years). The rural urban ratio is about 70:30. This has an implication for the distribution of resources since all secondary and tertiary institution are located in the urban areas and there by accessible only to about $30 \%$ of the population [10].

The population structure determined by the high crude birth rate (56 per 1,000), and high but declining crude death rate $(15$ per 1,000$)$ is characterized by a young population, high dependency ratio and low geriatric age group. The maternal mortality ratio (MMR) in 2007 was 1,000 per 100,000 live births. The birth rate represents strain on maternal and child Health (MCH) Services. Trained health personnel take in deed only about $65 \%$ of deliveries. The leading causes of MMR include spontaneous abortion, haemorrhage, anaemia, obstructed labor, eclampsia, etc. the total fertility rate is about 6.7 children per women. This is quite high and reflects in the rapid growth in population [9].

Notwithstanding, predominant occupation is agriculture, literacy level of low, persistent high level of infant mortality and maternal mortality rates points to the low standard of public health. Over $40 \%$ of hospitalized deaths occurring annually are accountable by common infectious diseases for which effective preventive measures are known [10].

\section{Notifiable Diseases}

The pattern of morbidity and mortality in the state appears not to deviate remarkably from overall estimates for the nation while no precise age or disease specific data are presently available, a number of indicators (Hospital case report, outpatient visit statistics, epidemiological reports, experience and observations over the years in the state). Suggest that malaria, Dysentery, Gastroenteritis/Cholera, Pneumonia, Cerebrospinal Meningitis (CSM) and measles together with nutritional problems continue to constitute the major cause of morbidity. Case fatality data from hospitals while in complete indicates that infectious and parasitic disease as well as respiratory conditions, together with accidents, child birth and nutrition related disorders also constitute the major causes of hospital admissions. The commonest seasonal diseases epidemic being experience in the state annually is cerebrospinal meningitis (CSM), Measles [9].

\section{Manpower and the Distribution of Health Infrastructure}

Central attention is drawn to the issue of work force (manpower) which is grossly inadequate particularly in the professional group. The attrition rate in the professional group is high and this situation has created a problem in our efforts to render effective and efficient services to the public. In 2003, there were 18 Hospital in Katsina State with 1,643 beds and a bed/population ratio of 1:3:13. By the end of 2007, the total number of hospitals in the State increase to 19 representing 5.5\% increase; while the available beds increased to 2885 ( $76.6 \%$ increase) and the bed/population rate stood at $1 / 2,068$ persons [10].

In addition, there are 1 Medical Centre and 1,261 different Health institutions in the state besides hospitals, which form the basis of health care delivery system in the rural areas of the state. These are 24 comprehensive Health Centers, 87 primary Health Centers, 504 Health Centers, 41 Dispensaries, and 90 Maternal and Child Health/Child Welfare clinics. 81 Health posts etc. these facilities are managed by the Local Government Health Departments. However, the ever increasing number private health institutions (50), 21 Pharmaceutical Shops and 1,703 patent Medicine Shops operation in all the nook and corners of the LGAs also complement the effort of the Governments in providing access to quality and affordable health care services in the rural and urban areas of the state [9]

\section{Referral System}

The categorization of health facilities in Katsina State is based on the referral system flow pattern, first levels of contact are health clinics followed by the Primary Health Centers and Comprehensive Health Centers. These together form the Primary level of health care; cases from primary level are referred to General Hospitals and Specialist/ hospital in that order. The General and Specialist hospitals form the secondary level of health care. Difficult cases from the secondary level are referred to the teaching hospital or Federal Medical Centers which form the tertiary level of health care. However the referral system has not been functioning effectively due to inadequate resources (e.g. drugs, manpower equipment/materials) and inaccessibility of these facilities to majority of the people in the state [10].

\section{Availability and Accessibility}

The existing number of hospitals in Katsina State is quite inadequate to cater for the secondary health needs of the populace (in 34 LGAs). The limited accessibility of the rural majority to good (superior) health care, the urban base medical programs and the apparent neglect of the rural areas in the allocation of socio-economic infrastructure have continued to underscore the magnitude of health related problems facing the people of the state [10].

\section{Primary/Secondary Health Care}

An important aspect of the next 10 years plan (2007-2016) period will be to increase the primary health care activities and coverage. However, this will not be done to the detriment of secondary health care which is already lacking essential facilities and infrastructures. Related to this will be emphasis in the individual role in disease prevention and 
health promotion and responsibility of the community in the healthrelated activities.

\section{Theoretical Framework}

Although, there are several theories related to the topic in question, ranging from the ancient world, through the spectacular interlude of the middle ages, down to the current episode in the progress of humanity. Nevertheless, this research work will consider the outstanding, yet most remarkable one(s) that could stand the test of time. The theories ran thus:

\section{Miasma theory of disease}

The miasmatic theory of disease held that diseases such as cholera, Chlamydia or the Black Death were caused by a miasma (ancient Greek: "pollution"), a noxious form of "bad air". This concept has been supplanted by the germ theory of disease. Miasma was considered to be a poisonous vapor or mist filled with particles from decomposed matter (miasmata) that caused illnesses. The wide acceptance of miasma theory during the cholera outbreaks overshadowed the partially correct theory brought forth by John Snow that cholera was spread through water. This slowed the response to the major outbreaks in the Soho district of London and other areas.

Another proponent of the miasmatic theory was Crimean War nurse Florence Nightingale (1820-1910), who became famous for her work in making hospitals sanitary and fresh-smelling [1].

Miasma explained why cholera and other diseases were epidemic in places where the water was un-drained and very foul-smelling. The theory led to improvements in the sanitation systems, which coincidentally led to decreased episodes of cholera, thus helping to support the theory. Even though the miasmatic theory has been disproven by the discovery of viruses and bacteria, it helped make the connection between poor sanitation and disease [2].

\section{Malthusian theory of population}

Reverend Thomas Robert Malthus' population theory remained an important back born of this research. In his famous treatise 'Essay on the principles of population' in the year 1798 Malthus made a crucial attempt to explain the trend of development of both the socioeconomic and political institutions in Europe. His theory postulate that the power of population is so superior to the power of earth to produce subsistence for man, that premature death must in some shape or other visit the human race. This model equally explains the proposition that an increase in population would have greater impact on health status of the society as a whole [11].

Malthus regarded ideals of future improvement in the lot of humanity with skepticism, considering that throughout history a segment of every human population seemed relegated to poverty. He explained this phenomenon by arguing that population growth generally expanded in times and in regions of plenty until the size of the population relative to the primary resources caused distress. With poverty, people cannot afford good health care services, clean environment and knowledge about public health generally.

Hence, for the purpose of this study, these theories (miasma and Malthusian theory) were selected as the basis or model for this research. In other words, the theories were adopted to serve as a theoretical framework backing up the research work. This is owing to their persuasive capacity to explain the contemporary phenomena as regards to the topic in question as well as the nature of the study area generally.

\section{Methodology}

The main sources of data that form the basis of analysis for this study were obtained from primary and secondary sources. Under primary source of data, structured questionnaire was employed, while in the secondary source of data collection, textbooks, journals, articles, newspapers, and other papers presented at seminars and workshops were consulted. Also consulted are other relevant publications on the topic in question. The data were analyzed and discussed via descriptive statistical techniques of tables, percentages, mean and ranks as appropriately chosen for this kind of study [12].

The instrument was structured using a Five-point rating scale of 5 to 1 , from strongly agree, Agree, neutral, disagree and strongly disagree. Data obtained were analyzed using mean scores. The criterion mean was determined at 2.50 . Thus, item that score 2.50 and above was accepted whilst those with a mean score less than 2.50 were rejected.

The study used a sample of 120 respondents based on purposive and judgmental sampling techniques owing to the fact that not all the elements of the population in the state has knowledge and analytical power on the state of health economy in the study area, hence the rationale behind the choice of the sample in question.

However, Katsina state has three (3) senatorial districts namely; Katsina central, Daura and Funtua Zones respectively. Thus, with the help of the Katsina State Epidemiologist, 40 questionnaires were successfully administered and retrieved to and from the health personnel across the zones in the state in general. Similarly, secondary data on manpower distribution and other important health indicators/ reports were elicited from the State Health Information Management Board.

\section{Results and Discussion}

\section{Section A: General criteria}

Age refers to the extent to which a person has lived or stays alive. In this study, $19.17 \%$ of the respondents fall within the age limit of $18-27$ years. $39.17 \%$ of the respondents fall within the age bracket of $28-37$ years of age, $31.66 \%$ of the respondents are within age bracket of $38-47$ years of age, $12 \%$ of the respondents are within age bracket of 48 -above year's age as depicted above (Table 1).

Gender refers to the sex status of an individual, that is either male or female, boy or girl, man or woman. In this study, male respondents constituted $74.17 \%$ whilst female respondents constituted the remaining $25.83 \%$.

Marital status can be seen as the fact of somebody's being married, unmarried or formally married. This is purely a marital phenomenon that is trying to show whether entrepreneur is single, married, divorced, or widow. The table shows that $11.66 \%$ of the respondents are single, $81.67 \%$ of the respondents are married. Meanwhile, $2.50 \%$ of the other respondents are divorce with the remaining $4.16 \%$ of the respondents widowed as depicted in the table above. Therefore, most of the respondents in the study area are married and singled as reflected by the house hold size, that they have much family responsibilities and having none family size. Marital status determines household size since married respondents tend to have a larger household size and hence, the majority of the respondents.

Qualification also refers to the learning, training, and skills acquired from the various schools and institutions of education. The training and 


\begin{tabular}{|c|c|c|}
\hline Variables & Frequency & Percentage (\%) \\
\hline \multicolumn{3}{|l|}{ Age } \\
\hline $18-27$ & 23 & 19.17 \\
\hline $28-37$ & 47 & 39.17 \\
\hline $38-47$ & 38 & 31.66 \\
\hline 48-above & 12 & 10 \\
\hline \multicolumn{3}{|l|}{ Gender } \\
\hline Male & 31 & 25.83 \\
\hline Female & 89 & 74.17 \\
\hline \multicolumn{3}{|l|}{ Occupation } \\
\hline Civil servant & 80 & 66.67 \\
\hline Farming & 20 & 16.67 \\
\hline Business & 15 & 12.5 \\
\hline Other (specify) & 5 & 4.16 \\
\hline \multicolumn{3}{|l|}{ Marital status } \\
\hline Single & 14 & 11.66 \\
\hline Married & 98 & 81.67 \\
\hline Widow & 3 & 2.5 \\
\hline Divorce & 5 & 4.16 \\
\hline \multicolumn{3}{|l|}{ Education } \\
\hline Primary & 4 & 3.33 \\
\hline Secondary & 26 & 21.67 \\
\hline Tertiary & 87 & 72.5 \\
\hline Other (specify) & 3 & 2.5 \\
\hline Total & 120 & 100 \\
\hline \multicolumn{3}{|c|}{ Source: Fieldwork, 2018} \\
\hline
\end{tabular}

Table 1: Socio-economic characteristics of the respondents.

skills acquired from the schools and institutions enhances individual capacity to carry out duties as expected and diligently. The table consists of the qualification of the respondents in which case; Majority of the respondents $(72.50 \%)$ have tertiary level of education, respondents with secondary school level of education constitutes $21.67 \%$. However, $3 \%$ of the other respondents hold primary school level of education, whereas $3 \%$ of the remaining respondents have other form of education such as vocational training, distance learning and other non-formal system of education.

$36.67 \%$ of the respondents believed that illiteracy is the leading factor responsible for the major health problems facing those localities. $19.17 \%$ on the other hand, attribute these problems to improper environmental sanitation. Yet, $17.50 \%$ suggest that contaminated water is responsible for the major health problems facing their locality. While $16.67 \%$ among the respondents are of the opinion that dumping refuse is the main cause of these health problems in the study area. Therefore, going by the miasma theory of diseases, lack of knowledge coupled with improper sanitation of environment or awareness (which explain illiteracy) are the leading factors responsible for the emergence of health problems in the society. That is why, the theory along the way enhances creating awareness (health education) and enhancing cleanness to improve health status and avoid health problems in a society (Table 2).

With regards to the question of way forward to the current health dilemmas in the study area $55 \%$ of the respondents opined that government can control the major health problems in the study area through public enlightenment. Notwithstanding, $25.83 \%$ of the respondents maintained that provision of qualified health personnel is the only answer to these problems. Moreover, $10 \%$ respondents believed in the idea of providing adequate medical facilities to the area, as the only solution they feel desirable. However, 7 respondents constituting $5.83 \%$ argue that through non-governmental organizations (NGO's) government can strikes an end to these adverse health problems. The remaining $3.33 \%$ of the respondents believed that government can control major health problems via other measures (Table 3).

As to the category of those to be blame for the major health problems facing the study area $32.5 \%$ of the respondents say 'government' should be blame for these problems while $25.83 \%$ felt that the blame should be on the people and not anyone else. Yet still others totaling to about $21.67 \%$ opined that, the educated elites should be blame for these problems. But surprisingly enough, $18.33 \%$ argue that the wealthy individuals are the best category to be blame for these health problems in these localities. The remaining $1.67 \%$ of the respondent puts the blame on other community members (Table 4 ).

From the data above, 93 respondents which constitute $77.5 \%$, respond to "YES" that there is of course decrease in the adverse effect of the major health problems in their locality. While 16 respondents making up $13.33 \%$ out of the entire responses says contrary. Yet the remaining $9.17 \%$ of the respondent remain undecided as depicted above. This (simply) follows from the fact that there is now awareness on the part of the society (as whole) that most of the health problems that constrained the health status of the study area were drastically reduced. Because government engaged itself in the development of manpower i.e. health personnel, in which case the supply of doctors including Nurses and midwives were given a serious consideration. Therefore, the respondents are fully aware of the health programs and initiatives by the government both at state and local government level and hence maintained that the current health status of those localities

\begin{tabular}{|c|c|c|}
\hline Causes & Frequency & Percentage (\%) \\
\hline Dumping refuse & 20 & 16.67 \\
\hline Contaminated water & 21 & 17.5 \\
\hline Illiteracy & 44 & 36.67 \\
\hline Improper sanitation & 23 & 19.17 \\
\hline $\begin{array}{c}\text { Others (Specify } \\
\text { Please) }\end{array}$ & 12 & 10 \\
\hline Total & 120 & 100 \\
\hline \multicolumn{2}{|c|}{} \\
\hline
\end{tabular}

Table 2: Which among the followings is responsible for the major health problem commonly found in your locality?

\begin{tabular}{|c|c|c|}
\hline Ways & Frequency & Percentage (\%) \\
\hline Through public enlightenment & 66 & 55 \\
\hline $\begin{array}{c}\text { Through non-governmental } \\
\text { organizations (NGOs) }\end{array}$ & 7 & 5.83 \\
\hline $\begin{array}{c}\text { Provision of qualified health } \\
\text { personnel }\end{array}$ & 31 & 25.83 \\
\hline $\begin{array}{c}\text { Provision of adequate medical } \\
\text { facilities }\end{array}$ & 12 & 10 \\
\hline Others (Specify Please) & 4 & 3.33 \\
\hline Total & 120 & 100 \\
\hline \multicolumn{2}{|c|}{ Source: Fieldwork, 2018 } \\
\hline
\end{tabular}

Table 3: How could government control the major health problems in your locality?

\begin{tabular}{|c|c|c|}
\hline Category & Frequency & Percentage (\%) \\
\hline The government & 39 & 32.5 \\
\hline The people & 31 & 25.83 \\
\hline The wealthy individuals & 22 & 18.33 \\
\hline Educated elite & 26 & 21.67 \\
\hline Others (Specify Please) & 2 & 1.67 \\
\hline Total & 120 & 100 \\
\hline \multicolumn{2}{|c|}{ Source: Fieldwork, 2018 } \\
\hline
\end{tabular}

Table 4: Who are to be blame for the major health problems facing your locality? 
is appreciating considerably. Consequently, this can be judged from existing health cases records in the study area where the rate of people affected with malaria diseases, Diarrhoea, and Typhoid are every day decreasing, simply because high priority is given to the sector now. Thus, this is a laudable achievement credited to the government, and is always been televised to make the people aware and to let them have an insight in what affect their health status generally. This explains the reason why majority respondents opined that there is a persistent decrease in the effect of the major health problems in the study area which has equally shown that government is given a due consideration to health sector (Table 5).

From the data tabulated above (Table 6), it can be seen that $65 \%$ of the respondents believed that provision of adequate health personnel and medical facilities can serve as important solution to the problems of the commonest diseases (Diarrhoea/Malaria/Typhoid) in such localities. On the other hand, only $26.60 \%$ argue out contrary. The remaining $8.33 \%$ of the respondents remain undecided. Obviously, efficiency is said to be attained best in the presence of optimality. These is no gainsaying that the case study area need available health workers and medical facilities (although there is improvement compared to the periods before now) within which the war against epidemic diseases and other endemic ailments can best be fought and assure victory at last. This is why $84.3 \%$ do believed that increase in the availability of those mentioned aspect can serve as a water-shed to the current health problems in the study area. The major reason behind their propositions is that none of the local government areas in the state has sufficient health facilities and workers, and most of the workers are not as efficient as those in the secondary and tertiary level of health care. Thus, inefficiency which was due to the lack of available health facilities and workers is the major reason surrounding their arguments. Finally, $26.60 \%$ are completely contrary to the opinion beheld by the majority category. They profess that even if the above provisions were supplied, it will certainly be ineffective to address the ailing problems unless the philosophy of the beneficiaries is significantly re-shaped.

Of the debate whether poverty cause malaria/diarrhea/typhoid in study area or Not; 64 respondents constituting 53.33\% respond to the opinion that 'YES' poverty causes those health problems in the study area. On the contrary, however, $3.17 \%$ respondents do believe 'NOT'. $12.50 \%$ of the remaining respondents remain neutral as shown in the table above. Consequently, this comes to explain the relationship between economy and health in the society. Poverty is generally considered as a threat to the masses who suffers from it. Most of the

\begin{tabular}{|c|c|c|}
\hline Response & Frequency & Percentage (\%) \\
\hline Yes & 93 & 77.5 \\
\hline No & 16 & 13.33 \\
\hline Undecided & 11 & 9.17 \\
\hline Total & 120 & 100 \\
\hline \multicolumn{2}{|c|}{ Source: Fieldwork, 2018 } \\
\hline
\end{tabular}

Table 5: Is there any decrease in the adverse effects of the major health problems in your local government area?

\begin{tabular}{|c|c|c|}
\hline Response & Frequency & Percentage (\%) \\
\hline Yes & 78 & 65 \\
\hline No & 32 & 26.6 \\
\hline Undecided & 10 & 8.33 \\
\hline Total & 120 & 100 \\
\hline \multicolumn{2}{|c|}{ Source: Fieldwork, 2018 }
\end{tabular}

Table 6: Can the provision of adequate health personnel and medical facilities be a solution to the problem of Malaria/Diarrhoea/Typhoid in your locality? people (about 72\%) in the case study area are living below poverty line. That is why it is not startling in the local governments to find so many health problems which are peculiar only to area and which are specifically due to poverty. Mal-nutrition is a problem to mother and baby. Lack of adequate diet creates distortions in the health status of the people. In a nut-shell, poverty brings along the way the problem of (good) food hygiene, it can equally lead to improper sanitation of the environment and can force people to reside in a secluded area and consume water that is totally contaminated. Thus, causing, Malaria/ Diarrhoea/Typhoid in the area. The Malthusian population theory can equally help to explain this phenomenon. As maintained by Malthus; when population outweigh the capacity of land to provide subsistence for men, then the likely inclination will result in premature death in the form of poverty which causes a lot of diseases. That is why $53.33 \%$ of the respondents believed that poverty lead to the emergence of many health problems in the study area, because they are fully aware of the vicious cycle of poverty and how it inflict the health status among which includes mal-nutrition, ulcer, typhoid, malaria and diarrhoea to mention but a few. That is why poor countries experience many health problems than the rich nations. Obviously because poverty is more or less a phenomenon that exist in the poor countries. Finally, this also tells us that in order to maintain adequate health of the citizens; society must conquer poverty (Table 7 ).

The Table 8 above shows that $68.33 \%$ respondents believe by saying 'YES' that donation from private individuals and NGO's can help to address the health problems facing the study area. Only $21(17.50 \%)$ respondents respond to 'NO' by saying contrary to the opinion of the first category. The remaining $5 \%$ of the respondents remain undecided. This is simply because, most of the respondent knows and are fully aware of the role played by these organizations (NGOS) especially in conquering poverty which bedeviled their health status. It was around the year 2006, that UNICEF engaged itself in the war against malnutrition in Daura zone, which specifically inflicts maternity and causes maternal death (both of mother and baby). UNICEF and other NGOs donated a lot of assistance including; food stuff, milk for the baby and host of others that will maintain the health status of the people of Daura zone generally, and the case study area were not in exception, but inclusive. Henceforth, it is owing to this that 61.7 believed in the intervention by private individuals and NGOs in addressing those health problems, WHO, UNICEF, and GAVI to mentioned but a few have been assisting the study area so many years ago and laudable progress has been recorded.

\begin{tabular}{|c|c|c|}
\hline Response & Frequency & Percentage (\%) \\
\hline Yes & 64 & 53.33 \\
\hline No & 41 & 34.17 \\
\hline Undecided & 15 & 12.5 \\
\hline Total & 120 & 100 \\
\hline \multicolumn{2}{|c|}{ Source: Fieldwork, 2018 } \\
\hline
\end{tabular}

Table 7: Can poverty cause Malaria/Diarrhoea/Typhoid in your locality?

\begin{tabular}{|c|c|c|}
\hline Response & Frequency & Percentage (\%) \\
\hline Yes & 93 & 68.33 \\
\hline No & 21 & 17.5 \\
\hline Undecided & 6 & 5 \\
\hline Total & 120 & 100 \\
\hline \multicolumn{2}{|c|}{ Source: Fieldwork, 2018 } \\
\hline
\end{tabular}

Table 8: Can donations from private individuals or organizations be a solution to the problem of Malaria/Diarrhoea/Typhoid in your locality? 
The responses from the above Table 9 indicate that $68.33 \%$ respondents opined 'YES' that high population density affects public health status. However, $17.50 \%$ of the remaining respondents maintained that high population density cannot affect public health status in those localities while the remaining $14.17 \%$ remain undecided. It is a general fact that most of the respondents are more or less educated. For, majority of them has secondary and tertiary level of education. Thus, they have the power to assess the impact of increasing population on their health status. Increase in population without proportionate increase in the supply of manpower and health facilities affect efficiency. Each of the local government has only 1 doctor indicating that he/she alone is responsible for the entire peoples' health. The more population increase the more the efficiency in the service delivery is affected, and the more the ratio of population to bed, to nurse, and to midwife changes negatively. Malthus' population theory can equally assist in explaining these phenomena. Where population increases persistently beyond the level of resources (Doctors, Nurses, midwives Beds, drugs etc.) required maintaining its equilibrium level; the subsequent aftermath would be the problem of inefficiency and premature death to some extent. Thus, because the respondents in the case study area are well aware of the assertion of persistent increase in population ceteris-Paribus (all things being equal), that is the major reason why they believed so i.e. high population causes Malaria, Typhoid, and Diarrhoea. It is equally important at this juncture to assert that congestion (high population) can easily serve as a means of transmitting certain diseases because some disease are communicable in nature, the respondents believed that high population in their area as a result of annual recycling of marriage is a threat to their health status and not a blessing.

As to the question of whether or Not traditional values has any connection with public health management in the study area, $45.83 \%$ response to 'YES' that strong adherence to traditional values (attitudes \& customs) is responsible for most of the health problems that the area is currently experiencing. While $31.67 \%$ argue out contrary. Remaining $22.50 \%$ of the respondents remain undecided. This however, shows that the values and tradition of their forefathers were still maintained with dignity. Equally vital at this juncture was the issue of efficiency. In fact, the services provided by the available (scarce) doctors, midwives, and nurses for instance are not so effective to displace the institutional beliefs of the population in the case study area. The citizens' customs and tradition was fully maintained, and this is why they prefer the services of their traditional doctors and traditional birth attendants to that of medical doctors, nurses and or midwives. The people practiced many events that can cause a serious health problem if not well considered and prevented. For example, when a pregnant woman is bleeding too much, it symbolizes blessings to the some areas in the state, as the mother will certainly give birth to a boy (male) which is considered as laudable blessings. But clearly, this is a serious health issue which is being televised and caution by government every day. Thus, the inability of the doctors, nurses and midwives available in the case study areas to revolutionize the institutional beliefs of the people and to champion their loyalty is the major reason why $87.8 \%$ of the respondent believed that strong adherence to traditional values is an important factor that

\begin{tabular}{|c|c|c|}
\hline Response & Frequency & Percentage (\%) \\
\hline Yes & 82 & 68.33 \\
\hline No & 21 & 17.5 \\
\hline Undecided & 17 & 14.17 \\
\hline Total' & 120 & 100 \\
\hline \multicolumn{2}{|c|}{ Source: Fieldwork, 2018} \\
\hline
\end{tabular}

Table 9: Can high population density affects public health status in your locality? causes several health problems in those communities. Although the people are now embracing western education and are to some extent aware of some factors that causes certain disease in the area. Yet, they are conservative and stringent in terms of their customs and traditional beliefs (Table 10)

The above Table 11 shows that 81 respondents constituting $67.50 \%$ of the respondents response to 'YES' that malaria/diarrhea/typhoid are of course deadly diseases responsible for massive death rate in the study area. On the contrary, $26.67 \%$ respondents who respond to 'NO' believed that massive death rate was not as a result of such disease or cannot be attributed to Malaria/diarrhea/typhoid in such communities. Yet, $5.83 \%$ of them remain undecided. Notwithstanding, the respondents were of course acquainted with the current phenomena as regards to the health-drama in their localities and this can be judged from the socio-economic characteristics (Age, level of education, occupation etc.) of the respondents, in which case we concludes that the sample population appears to be good sample representing truly the population under study. Nonetheless, the obvious fast surrounding the argument of the majority respondents i.e. $87.8 \%$ is that the rate of death which was due to Malaria/Diarrhoea/Typhoid in those communities is persistently high. Although, it is not possible to get the actual records pertaining to the death rate (no. of deaths) resulting from such diseases in record books available in the hospital/clinics in the study area which was certainly due to poor record keeping, yet the followings are important index through which one can put forward his generalization as regards to the argument in question.

\section{Section B: Assessing the public health status of Katsina state}

As to those factors which most improve the quality of life in a community, above table shows that healthy behavior and life styles was ranked the first, followed by access to health care services (e.g. family doctor). Clean environment occupies the $3^{\text {rd }}$ position. This went consistent with the fact that most of the common health problems facing those areas were basically environment oriented diseases which are communicable in nature. That was why the respondents rated healthy behavior, access to health care services and clean environment as their 3 major factors or practices which mostly improve the quality of life and healthy community in general. Other supporting factors include among others strong economy with opportunities, low adult death and disease rate as well as low infant deaths (Table 12).

As to those problems which have the greatest impact on overall

\begin{tabular}{|c|c|c|}
\hline Response & Frequency & Percentage (\%) \\
\hline Yes & 55 & 45.83 \\
\hline No & 38 & 31.67 \\
\hline Undecided & 27 & 22.5 \\
\hline Total & 120 & 100 \\
\hline \multicolumn{2}{|r|}{ Source: Fieldwork, 2018 } \\
\hline
\end{tabular}

Table 10: Do you think strong adherence to traditional values is responsible for most of the health problems that your locality is facing?

\begin{tabular}{|c|c|c|}
\hline Response & Frequency & $\begin{array}{c}\text { Percentage } \\
\text { (\%) }\end{array}$ \\
\hline Yes & 81 & 67.5 \\
\hline No & 32 & 26.67 \\
\hline Undecided & 7 & 5.83 \\
\hline Total & 120 & 100 \\
\hline \multicolumn{2}{|c}{ Source: Fieldwork, 2018} \\
\hline
\end{tabular}

Table 11: Can Malaria/Diarrhoea/Typhoid be responsible for massive death rate in your locality? 
community health, high blood pressure was rated the first, followed by the diabetes and finally infectious diseases which are commonly found in all the nooks and crannies of the state in general. This is not startling considering the fact that, economic frustrations, social vices and political cog mires surrounding the polity are what trigger the important health problems slated above. Other important health problems in the community include sexually transmitted diseases, infant deaths, heart disease/break, mental health problems, respiratory/ lung disease, teenage pregnancy and homicide among others. Most of these problems have long run bearing (effect) on the economy as a healthy nation is wealthy nation (Table 13).

As to those behaviors which have the greatest impact on overall community health, it was found that drug abuse, dropping out of school, and being overweight are the three (3) important risky behaviors that may generate or trigger health tension in our community. Others include tobacco use, not using birth control measure, unsafe sex, not using contraception methods, poor eating habits, alcohol abuse, not getting shots to prevent disease, lack of exercise, racism and other behavior not explicitly stated here (Table 14).

The results above Table 15 shows that, the study area was rated very unhealthy by the majority respondents (26.67\%), $22.50 \%$ of the other respondents rated it somewhat healthy. Yet, $20.50 \%$ of the respondents rated the study area as very healthy. $18.33 \%$ of the other respondents rated the study area as unhealthy whereas, the remaining $12.50 \%$ rated it as healthy as depicted above. However, considering the report on the various health challenges across the different health facility in the state as well as the distribution of health manpower it is plausible to reiterates that the state of the study area is not healthy enough as to propel efficient and vibrant health economy.

Table 16 above shows that, $15.83 \%$ of the respondents rated their personal health as very unhealthy. $10 \%$ rated their own as unhealthy whereas, $25 \%$ of the other respondents rated theirs "somewhat healthy". However, $13.33 \%$ of the respondents rated their personal health status "healthy" while the remaining $35.83 \%$ who constituted the majority rated their own health status "very healthy". This to some extent reveals the fact that, on average, the community under study suffers from one form of ailment or the other attributable partly to deficiencies in the state's public health economy.

\section{Section C: Health infrastructure}

On the assessment of health infrastructure, table above shows that based on their respective means (average), it was found that, drugs for major health problems are free in my locality, Health services delivery is improving in the state, there is awareness as regards to free health services delivery in my locality, the state receives donations from private and other Non-Governmental Organizations and Government is trying to improve maternal and child health issues in my locality (Table 17).

\begin{tabular}{|c|c|c|}
\hline Factors & Mean & Ranking \\
\hline Good schools & 3.3 & $4^{\text {th }}$ \\
\hline Access to health care (e.g., family doctor) & 4.02 & $2^{\text {nd }}$ \\
\hline Strong Economy with Opportunities & 2.92 & $5^{\text {th }}$ \\
\hline Clean environment & 3.78 & $3^{\text {rd }}$ \\
\hline Healthy behaviors and lifestyles & 4.11 & $1^{\text {st }}$ \\
\hline Low adult death and disease rates & 2.77 & $6^{\text {th }}$ \\
\hline Low infant deaths & 2.43 & $7^{\text {th }}$ \\
\hline Source: Fieldwork, 2018 & \\
\hline
\end{tabular}

Table 12: Important factors for a "Healthy Community?"

\begin{tabular}{|c|c|}
\hline Health Problems & Ranking \\
\hline Cancers & $15^{\text {th }}$ \\
\hline Child abuse / neglect & $12^{\text {th }}$ \\
\hline Dental problems & $18^{\text {th }}$ \\
\hline Diabetes & $2^{\text {nd }}$ \\
\hline Domestic Violence & $13^{\text {th }}$ \\
\hline Firearm-related injuries & $11^{\text {th }}$ \\
\hline Heart disease and stroke & $6^{\text {th }}$ \\
\hline High blood pressure & $1^{\text {st }}$ \\
\hline Homicide & $10^{\text {th }}$ \\
\hline Infant Death & $5^{\text {th }}$ \\
\hline Infectious Diseases (e.g., hepatitis, TB, etc.) & $3^{\text {rd }}$ \\
\hline Mental health problems & $7^{\text {th }}$ \\
\hline Motor vehicle crash injuries & $14^{\text {th }}$ \\
\hline Rape / sexual assault & $16^{\text {th }}$ \\
\hline Respiratory / lung disease & $8^{\text {th }}$ \\
\hline Sexually Transmitted Diseases (STDs) & $4^{\text {th }}$ \\
\hline Suicide & $17^{\text {th }}$ \\
\hline Teenage pregnancy & $9^{\text {th }}$ \\
\hline \multicolumn{2}{|l|}{ Others (Specify Please) } \\
\hline Source: Fieldwork, & \\
\hline
\end{tabular}

Table 13: Three most important "health problems" in the study area?

\begin{tabular}{|c|c|c|}
\hline Risky Behaviors & Mean & Ranking \\
\hline Alcohol abuse & 2.62 & $9^{\text {th }}$ \\
\hline Being overweight & 4.01 & $3^{\text {rd }}$ \\
\hline Dropping out of school & 4.25 & $2^{\text {nd }}$ \\
\hline Drug abuse & 4.78 & $1^{\text {st }}$ \\
\hline Lack of exercise & 2.2 & $11^{\text {th }}$ \\
\hline Poor eating habits & 2.77 & $8^{\text {th }}$ \\
\hline Not getting "shots" to prevent disease & 2.45 & $10^{\text {th }}$ \\
\hline Racism & 1.96 & $12^{\text {th }}$ \\
\hline Tobacco use & 3.64 & $4^{\text {th }}$ \\
\hline Not using birth control & 3.32 & $5^{\text {th }}$ \\
\hline Not using seat belts / child safety seats & 2.98 & $7^{\text {th }}$ \\
\hline Unsafe sex & 3.12 & $6^{\text {th }}$ \\
\hline Other (Specify Please) & 1.67 & $13^{\text {th }}$ \\
\hline Source: Fieldwork, 2018 & & \\
\hline
\end{tabular}

Table 14: Most important "risky behaviors" in the study area?

Conversely, it was found based on the average mean scores that, there is no availability of health manpower in the state, there are no sufficient beds, wheel-chairs, ambulances and other health infrastructure in the state. People in the state do not prefer the services of traditional herbalists to modern health professionals; there is no sound interconnection and feedback between primary health care units, secondary health care unit and tertiary health care unit. Katsina state do not benefits from health campaign geared towards promoting accessibility to health care services as depicted in the table above.

\section{Section D: Distribution of health manpower in Katsina state}

Table 18 above presents the distribution of the health manpower across Katsina state in which case the ratio of some important indicators shows that doctor to population ratio stood at 1:67,415; ratio of nurses to population stood at 1:16086; ratio of midwives to female population was put at 1:13423. However, considering the ongoing upheaval in the global art of public health economy, it is plausible to recast that, Katsina state needs to further strengthen the efficacy of public health economy 
Citation: Abubakar UL, Abdurrahman A (2018) An Assessment of Public Health Economy in Katsina State. Health Econ Outcome Res Open Access 4: 160. doi: $10.4172 / 2471-268 \times / 1000160$

Page 8 of 9

\begin{tabular}{|c|c|c|}
\hline Rating & Frequency & $\begin{array}{c}\text { Percentage } \\
\text { (\%) }\end{array}$ \\
\hline Very unhealthy & 32 & 26.67 \\
\hline Unhealthy & 22 & 18.33 \\
\hline Somewhat healthy & 27 & 22.5 \\
\hline Healthy & 15 & 12.5 \\
\hline Very healthy & 24 & 20 \\
\hline Total & 120 & 100 \\
\hline \multicolumn{2}{|c|}{ Source: Fieldwork, 2018 } \\
\hline
\end{tabular}

Table 15: How would rate Katsina state as a "Healthy Community?"

\begin{tabular}{|c|c|c|}
\hline Rating & Frequency & $\begin{array}{c}\text { Percentage } \\
\mathbf{( \% )}\end{array}$ \\
\hline Very unhealthy & 19 & 15.83 \\
\hline Unhealthy & 12 & 10 \\
\hline Somewhat healthy & 30 & 25 \\
\hline Healthy & 16 & 13.33 \\
\hline Very healthy & 43 & 35.83 \\
\hline Total & 120 & 100 \\
\hline Source: Fieldwork, 2018 \\
\hline
\end{tabular}

Table 16: How would rate your own personal health?

\begin{tabular}{|c|c|c|c|c|c|c|c|c|}
\hline \multirow[b]{2}{*}{$\begin{array}{c}\text { S/ } \\
\text { No. }\end{array}$} & \multirow[b]{2}{*}{ Statement } & \multicolumn{5}{|c|}{ Response } & \multirow[b]{2}{*}{ Mean } & \multirow[b]{2}{*}{ Interpretation } \\
\hline & & $\begin{array}{l}\text { SA } \\
(5)\end{array}$ & $\begin{array}{c}A \\
(4)\end{array}$ & $\begin{array}{c}U \\
(3)\end{array}$ & $\begin{array}{l}D \\
(2)\end{array}$ & $\begin{array}{l}\text { SD } \\
(1)\end{array}$ & & \\
\hline 1. & $\begin{array}{l}\text { There is availability of health } \\
\text { manpower in my locality. }\end{array}$ & 09 & 17 & 12 & 33 & 49 & 2.25 & Reject \\
\hline 2. & $\begin{array}{l}\text { Drugs for major health } \\
\text { problems are free in my } \\
\text { locality. }\end{array}$ & 18 & 33 & 18 & 35 & 16 & 2.75 & Accept \\
\hline 3. & $\begin{array}{c}\text { There are sufficient beds, } \\
\text { wheel-chairs, ambulances } \\
\text { and other health } \\
\text { infrastructure in my locality. }\end{array}$ & 11 & 22 & 09 & 47 & 31 & 2.17 & Reject \\
\hline 4. & $\begin{array}{l}\text { Health services delivery is } \\
\text { improving in my locality }\end{array}$ & 18 & 36 & 20 & 29 & 17 & 2.60 & Accept \\
\hline 5. & $\begin{array}{l}\text { There is awareness as } \\
\text { regards to free health } \\
\text { services delivery in my } \\
\text { locality. }\end{array}$ & 32 & 25 & 02 & 23 & 38 & 2.70 & Accept \\
\hline 6. & $\begin{array}{c}\text { My locality receives } \\
\text { donations from private and } \\
\text { other Non-Governmental } \\
\text { Organizations }\end{array}$ & 19 & 28 & 24 & 36 & 13 & 2.56 & Accept \\
\hline 7. & $\begin{array}{l}\text { Government is trying to } \\
\text { improve maternal and child } \\
\text { health issues in my locality. }\end{array}$ & 33 & 27 & 12 & 28 & 20 & 2.68 & Accept \\
\hline 8. & $\begin{array}{c}\text { My locality preferred } \\
\text { services of traditional } \\
\text { herbalists to modern health } \\
\text { professionals. }\end{array}$ & 17 & 27 & 18 & 38 & 20 & 2.44 & Reject \\
\hline 9. & $\begin{array}{l}\text { There is sound } \\
\text { interconnection and } \\
\text { feedback between primary } \\
\text { health care unit, secondary } \\
\text { health care unit and tertiary } \\
\text { health care unit in my } \\
\text { locality. }\end{array}$ & 33 & 22 & 13 & 14 & 05 & 2.34 & Reject \\
\hline 10. & $\begin{array}{l}\text { My locality benefits from } \\
\text { health campaign geared } \\
\text { towards promoting } \\
\text { accessibility to health care } \\
\text { services }\end{array}$ & 12 & 26 & 31 & 22 & 29 & 2.33 & Reject \\
\hline & Sour & & elav & $\mathrm{K}, 2$ & 018 & & & \\
\hline
\end{tabular}

Table 17: Assessing the health infrastructure and other services.

\begin{tabular}{|c|c|c|}
\hline S/No. & Health Personnel & Number \\
\hline 1. & Doctors & 89 \\
\hline 2. & Nurses & 373 \\
\hline 3. & Midwives & 298 \\
\hline 4. & Community Health Officers (CHO) & 1520 \\
\hline 5. & Environmental Health Officer (EHO) & 782 \\
\hline 6. & Environmental Health Assistants & 497 \\
\hline 7. & Senior Community Health Extension & 1232 \\
\hline 8. & Workers & 1943 \\
\hline 9. & Wunior Community Health Extension & 551 \\
\hline 10. & Dental Health Technicians (DSTs) & 415 \\
\hline 11. & Labontal Surgery Assistants (DSAs) & 78 \\
\hline 12. & Nutritionist & 506 \\
\hline 13. & Health Attendants & 747 \\
\hline 14. & Traditional Birth Attendants (TBAs) & 103 \\
\hline 15. & Drivers & 144 \\
\hline \multicolumn{2}{r|}{} & Source: Ministry of Health, Katsina state profile, 2018 \\
\hline
\end{tabular}

Table 18: Manpower distribution.

to enable accessibility to health care services, enhancing productivity, civic society and curtailing the menace of maternal, ante and neonatal deaths that sabotage the very fabric of public health economy. In essence, priority should be accorded to supply of manpower and distribution to meet up the urgent and increasing demands for health care services in the realm.

\section{Conclusion and Recommendations}

Health is generally an intrinsic human right as well as a central input to poverty reduction and socio-economic development. Better health is central to human happiness and well-being. It also make an important contribution to economic progress as healthy populations live longer, are more productive, and more prone to saving more. Based on the findings in this paper, it was concluded that, in terms of manpower distribution/supply and its ratio to population, in terms of supply of available health infrastructure, in terms of perception and ratings of health care services and accessibility by the people across the state as well as the art and practice of public health paradigm suffers from the plague of deficiencies of finance, priority and goodwill necessary to propel the achievement of health for all goal in the long run. It is in the wake of these findings, the paper recommends for the state government in collaboration with the state Ministry of Health to:

1. Establish a ministerial Forum on Maternal, Newborn and Child Health.

2. Establish more women and children hospitals and provide them with appropriate essential medical equipment, physical infrastructure, referral facilities, human resources (trained in topics related to $\mathrm{MNCH}$ ), to ensure the provision of integrated quality health care.

3. Establish integrated $\mathrm{MNCH}$ and $\mathrm{RH}$ health services that include: Outpatient, inpatient, Antenatal care, Delivery care, Newborn care (nursery), post-natal care, child welfare services, family planning including outreach clinics and services and performing emergency obstetric care functions all under one roof/compound or within the same health facility.

4. Institutionalize outreach services to address maternal, newborn and child health care. 
5. Accelerate health promotion activities base on key household practices.

6. Collect and disseminate data and encourage the use of information generated for decision-making.

7. Enhance National health insurance scheme to cover the most vulnerable women and children.

8. HMIS units should have a threshold of minimum package at all levels to enable them function effectively. In addition, a budget line should be provided specifically for HMIS/M\&E in the State Annual Health Budget of the SMOH, HSMB, SPHCDA and LGAs to facilitate improved data collection, collation, analysis and publication of relevant documents and research.

9. There are 12 Development partners (programmes) and 7 Organizations National programmes currently complementing the health sector efforts of the government in the state. These include: WHO, UNICEF, DFID/ACCESS, USAID/ACQUIRED, USAID/COMPASS, EU/PRIME, Pathfinder international, USAID/GHAIN, SFH, and USAID/ENHANCE, UNFPA, DFID/ PRRINN, and polio plus (RI), Red Cross, NPHCDA, NACA, RBM project, National Malaria programme, and PPFN. Since their presence and activities (funding) are based on policy issues, the $\mathrm{SMOH}$ should coordinate and harmonize donor inputs (funding and policy priorities) and document their contributions in quantifiable terms. This will facilitate annual performance appraisal and writing letters of appreciation to any of them on successful completion of their programmes and the state could ask for additional interventions in areas of need. This is necessary and important because letters from $\mathrm{SMOH}$ or $\mathrm{FMOH}$ to Development partners is more authentic and recognized than communication from their parastatals.

10. The SMOH/SPHCDAL/LGAs should consider special allowance for rural posting to compensate for deprivation of access to social amenities available in urban areas.

11.There is need for small field surveys on immunization coverage in each of the three senatorial districts of the state to ascertain the true immunization coverage of the population, in view of the current discrepancies in the figures being reported, which seems to make accurate targeted objective difficult. To identify gaps (grey areas), considerable attention should be given to how knowledge flowed through the system of actors, processes and institutions to identify key challenges that support knowledge from research to practice.

12. The SMOH should perform its oversight role of the health sector effectively and efficiently to identify the strengths and weakness including the challenges militating against achievements of some objectives and proffer proactive solutions.

\section{References}

1. Wright H, Rapport S (1962) The amazing world of medicine. Victor Gollancz Ltd., London.

2. Kenneth AJ (1985) Theoretical issues in health insurance. University of Essex England.

3. Bhutta ZA, Ahmed T, Black RE, Cousens S, Dewey K, et al. (2008) What works? Interventions for maternal and child undernutrition and survival. Lancet 371: 417-440.

4. Garenne M, Gakusi E (2006) Health transitions in sub-Saharan Africa: overview of mortality trends in children under 5 years old (1950-2000). Bull World Health Org 84: 470-478.

5. World Health Organization (WHO) (2006) Macroeconomics and health investing in health for economic development. Reports of the Commission on Macroeconomics and Health.

6. Global Health Challenge (2010) An assessment of global health care. WHO, Geneva.

7. World Development Report: Investing in Health (2009) Oxford University Press, USA.

8. Lucas AO (2009) Public access to health information as a Human Right. Proc Int Symp Pub Health Surv 41: 77-78.

9. State Ministry of Health (SMOH) (2017) Katsina state health profile. Katsina, Nigeria.

10. State News Letter (SNL) (2005) Addressing Maternal Mortality. Aminia 14: 5-13

11. Bilyaminu IK (2005) Introducing environmental economics. Gidan-Dabino Publishers, Nigeria.

12. Osuala K (2007) Research methodology. University of Ibadan Press, Nigeria 